\title{
Surgical management of heart failure
}

\author{
Options increasing with new operative techniques and technology
}

$\mathrm{O}$ ver the past three decades mortality from cardiovascular disease has decreased in industrialised societies while the incidence and prevalence of heart failure has been increasing. ${ }^{1}$ Heart failure is now a major health problem, affecting up to $2 \%$ of the population and $10 \%$ of patients aged over 65 years. ${ }^{2}$ In 1990 heart failure accounted for 5\% of all hospital admissions in Britain, ${ }^{3}$ at a cost to the NHS of $£ 360 \mathrm{~m}(\$ 576 \mathrm{~m}){ }^{4}$ In the United States, where 400000 new cases are diagnosed annually, treatment costs in excess of $\$ 34 \mathrm{bn}(£ 21.2 \mathrm{bn}) .^{5}$

The natural course of heart failure is progressive so that even with angiotensin converting enzyme inhibitors, the only medical treatment to have consistently improved prognosis, the annual mortality is 25-50\%. ${ }^{5}$ This dismal outlook, particularly in severely symptomatic patients, often prompts surgical referral. A small proportion of patients may benefit from coronary revascularisation, albeit at a higher operative risk, ${ }^{6}$ while unsuspected or underestimated valvular disease may merit valve repair or replacement. For many, conventional cardiac surgery has little to offer and the only surgical option is transplantation. Newer surgical approaches include cardiomyoplasty, left ventricular volume reduction, and mechanical support.

Cardiac transplantation is presently the optimum surgical treatment for heart failure. Allograft transplantation results in 90\% survival at one year and 50\% survival at five years with return to a near normal quality of life. ${ }^{7}$ However, the scarcity of donor organs means that only about 300 heart transplants are performed annually in Britain and that fewer than half of potential recipients receive an organ, even when patients aged over 60 years are excluded from consideration. Longer term problems include a $60 \%$ prevalence of coronary artery disease by five years due to chronic immunological rejection, renal impairment due to cyclosporin toxicity, and an increased risk of malignancy because of chronic immunosuppression. Despite recent claims for transgenic porcine hearts and the potential for their "off the shelf" availability, rejection of xenotransplants is likely to be worse than for allografts and is unlikely to be solved by immunosuppressive agents alone. ${ }^{8}$ This, together with the possibility of retrovirus transmission, has led to the recent moratorium on progression to human xenotransplants. ${ }^{9}$

Cardiomyoplasty is the transposition of electrically transformed pedicled skeletal muscle to provide systolic or diastolic augmentation to the native heart. Most commonly, the latissimus dorsi is elevated to its origin and transposed through the chest wall to be wrapped around the failing heart. The rationale for cardiomyoplasty is that chronic low frequency electrical stimulation can transform the phenotype of skeletal muscle so that it becomes fatigue resistant. ${ }^{10}$ Among the conceptual attractions of cardiomyoplasty are the avoidance of rejection (and therefore the need for immunosuppressive drugs) and the possibility of electively scheduled surgery. However, enthusiasm for cardiomyoplasty has been tempered by an operative and first year mortality in excess of $30 \%{ }^{11}$ and little objective haemodynamic improvement in survivors despite a reported improvement in their quality of life. ${ }^{12}$

In the past few years implantable mechanical support devices have joined the list of long term options for heart failure. These devices, initially used in the 1960 s to completely replace the native heart in moribund patients awaiting transplantation, required fixed attachment of the patient to a bulky external console. In contrast, the current implantable left ventricular assist devices augment the function of the native heart and can be powered by portable battery packs. Their success in supporting patients awaiting transplantation over months ("bridge to transplantation"), allied to the growing imbalance between demand for and supply of hearts for transplantation, has encouraged their permanent implantation.

In Britain their clinical use is currently restricted to patients denied transplantation on the grounds of age or renal impairment. Two electrically driven left ventricular assist devices ( the Novacor and the Heartmate) are now available for long term implantation. Their major limitations are the risks of infection, thromboembolism, noise, and batteries that need to be charged every eight to 12 hours. The transcutaneous drive line between the device and its external power source inevitably predisposes to infection, although placing the device in the peritoneum and tunnelling the drive line reduce this risk. A counterintuitive approach has reduced the risk of thromboembolism: the interior of the Heartmate device consists of highly textured surfaces, forming a densely adherent layer of thrombus which acts as a template for neointimal growth. While a mechanical heart valve or the Novacor require warfarin, the Heartmate seems to be safe with aspirin, although there have been as yet no randomised controlled trials.

Two newer concepts show promise in the surgical treatment of heart failure. The Jarvik 2000 is an axial 
flow pump, about the size of a thumb (in contrast to the one litre volume displacement of' the Heartmate), designed to sit within the apex of the left ventricle and silently deliver non-pulsatile flow rates up to 10 litres per minute. Its long term physiological effects are still under investigation, but in animal models it has shown excellent haemodynamic performance without evidence of haemolysis. ${ }^{14}$ It is likely to be available for clinical use within a year.

Secondly, evidence is accumulating that prolonged support with left ventricular assist devices may allow at least some recovery of native cardiac function: sophisticated analysis of myocardial biopsies reveals normalisation of morphological features ${ }^{15}$ and handling of calcium by the sarcoplasmic reticulum is improved. ${ }^{13}$ Reports are now emerging of successful explant of devices after three to six months of support. ${ }^{16}$ This raises the fascinating possibility that mechanical intervention at an earlier stage in the course of certain types of heart failure, including viral myocarditis and dilated cardiomyopathy, might restore normal cardiac function ("bridge to recovery").

Most recently, the Brazilian surgeon Randas Batista has proposed reduction of left ventricular volume for dilated cardiomyopathy. This unconventional operation involves surgical resection of a large segment of ventricular muscle and results in a reduction in the radius and an increase in wall thickness of the left ventricle. The available (but as yet unpublished) clinical data on 300 Brazilian patients operated on in a rural hospital describe an intraoperative mortality of $15 \%$, but with $85 \%$ of the survivors improving from New York Heart Association functional class IV to functional class I or II. The results have proved sufficiently compelling for several American and European medical centres to embark on pilot trials. ${ }^{17}$

Many questions remain unanswered. The conceptual attractions of cardiomyoplasty and ventricular volume reduction are currently offset by substantive operative mortality. Left ventricular assist devices are inherently expensive, but randomised trials comparing them with medical treatment or transplantation may prove them cost effective. Should they be used at an earlier stage of heart failure in the hope of promoting native cardiac recovery? Would a silent, miniaturised, fully implantable device prove preferable to conven- tional transplantation or xenotransplantation with immunosuppression and other inherent problems? Is it possible that these different surgical approaches to heart failure might become complementary treatments at different stages of the disease, allowing the surgical procedure to be tailored to individual patients? The current lack of donor organs for transplantation adds urgency to the debate.

\section{David P Taggart \\ Consultant cardiothoracic surgeon Stephen Westaby \\ Consultant cardiothoracic surgeon}

Department of Cardiothoracic Surgery,

Oxford Health Centre,

Oxford Radcliffe Hospital,

Oxford OX3 9DU

1 Lenfant C. Report of the task force on research in heart failure. Circulation 1994;90:1118-23.

2 Kannel WB, Belanger AJ. Epidemiology of heart failure. Am Heart J 1992;121:951-7.

3 Sutton GC. Epidemiologic aspects of heart failure. Am Heart J 1990;120:1538-50

4 Nolan J, Kearney MT. Heart failure: an old problem. Br J Hosp Med 1995;54:43-6.

5 Costanzo MR, Augustine S, Bourge R, Bristow M, O’Connell JB, Driscoll $\mathrm{D}$, et al. Selection and treatment of candidates for heart transplantation. A statement for health professionals from the committee on heart failure and cardiac transplantation of the council on clinical cardiology? American Heart Association. Circulation 1995;92:3593-612.

6 Dreyfus GD, Duboc D, Blasco A, Vigoni F, Dubois C, Brodaty D, et al. Myocardial viability assessment in ischemic cardiomyopathy: benefits of coronary revascularization. Ann Thorac Surg 1994;57:1402-8.

7 Hosenpud JD, Novick RJ, Breen TJ, Daily OP. The Registry of the International Society for Heart and Lung Transplantation: eleventh official report-1994. J Heart Lung Transplant 1994;13:561-70.

8 Bach FH. Transplanting porcine hearts to humans. BMJ 1996;312:651-2.

9 Morris PJ. Pig transplants postponed. BMJ 1997;314:242.

10 Salmons S, Sreter FA. Significance of impulse activity in the transformaSalmons S, Sreter FA. Significance of impulse activit
tion of skeletal muscle type. Nature 1976;263:30.

11 Magovern GJ, Simpaon KA. Clinical cardiomyoplasty: review of the tenyear United States experience. Ann Thorac Surg 1996;61:413-9.

12 Chiu RC. Dynamic cardiomyoplasty for heart failure. $\mathrm{Br}$ Heart J 1995;73:1-3.

13 Frazier OH, Benedict CR, Radovancevic B, Bick RJ, Capek P, Springer $\mathrm{WE}$, et al. Improved left ventricular function after left ventricular unloading. Ann Thoracic Surgery 1996;62:675-81.

14 Kaplon RJ, Oz MC, Kwiatkowski PA, Levin HR, Shah AS, Jarvik KB, et al. Miniature axial flow pump for ventricular assistance in children and small adults. J Thorac Cardiovasc Surg 1996;111:13-8.

15 McCarthy PM, Nakatani S, Vargo R, Kottke-Marchant K, Harasaki H, James KB, et al. Structural and left ventricular histologic changes after implantable LVAD insertion. Ann Thorac Surg 1995;59:609-13.

16 Tayama E, Nose Y. Can we treat dilated cardiomyopathy using a left ventricular assist device? Artificial Organs 1996;20:197-201.

17 McCarthy PM. Ventricular remodelling: hype or hope? Nature Med 1996;2:859-60.

\section{Dietary treatment of active Crohn's disease}

\section{Fewer side effects but poorly tolerated and no more effective than corticosteroids}

$\mathrm{O}$ ral corticosteroids (usually prednisolone) have long been the standard treatment for active Crohn's disease, being used within 10 years of diagnosis in $55 \%$ of patients. Their efficacy has been established in two multicentre, placebo controlled trials. ${ }^{2}$ After four months, remission was shown in $60-83 \%$ of patients compared with $30-38 \%$ of those receiving placebo. However, there is currently much concern over side effects. In the short term these trials showed that corticosteroid treatment significantly increased the prevalence of cutaneous problems (moon face, acne, bruising, and striae), hypertension, and infections. In the long term there is concern over osteoporosis. Although the exact incidence is not known, substantial bone loss has been shown in patients taking at least $7.5 \mathrm{mg}$ prednisolone daily, and about a quarter of patients receiving long term treatment will experience a fracture. ${ }^{3}$

For these reasons, other treatments have been sought. In the past 12 years dietary treatment has been investigated in several centres with diets differing in their presentation of nitrogen: elemental diets contain- 


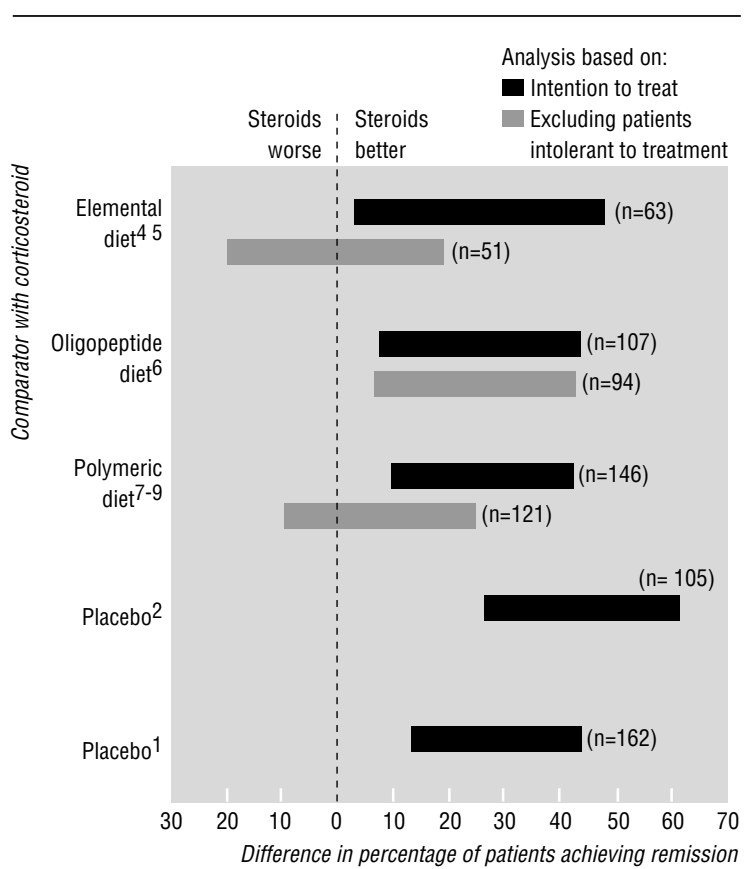

Pooled data from trials comparing dietary treatment with corticosteroids for treating active Crohn's disease. Bars show 95\% confidence intervals for difference in percentage of patients receiving each treatment going into remission

ing nitrogen as free amino acids, oligopeptide diets containing short chain peptides of 4-5 amino acids, and polymeric diets containing whole protein. Such diets are given orally or by nasogastric tube for two to four weeks, and all other food and drink except water is withheld. The theory is that an elemental diet might induce remission by reducing the immunological stimulation caused by whole protein while at the same time providing both nutrition and, by virtue of low residue, bowel rest.

The issue is not whether dietary treatment is better than corticosteroids, which are undoubtedly effective, but whether it is as good as corticosteroids at inducing remission while causing fewer side effects and being more acceptable to the patient. Several studies have compared dietary treatment with corticosteroids, ${ }^{4-9}$ and the results are shown in the figure. Each bar represents pooled data from all similar trials and is presented both in "intention to treat" form and after exclusion of all patients who could not tolerate either treatment. The dropout rate due to intolerance to the diets was high (11/33 on elemental diet, $7 / 55$ on oligopeptide diet, and $23 / 75$ on polymeric diet), giving a significant advantage for corticosteroids in all the trials. If intolerant patients are excluded the studies do show (at least for the elemental and polymeric diets) that diet may be as effective as corticosteroids. To show with adequate certainty that dietary treatment is as good as, or at least no more than $10 \%$ worse than, corticosteroids at inducing remission (with a level of significance of $10 \%$ and a power of $80 \%$ ), we estimate that 145 patients would need to receive each treatment. A trial of this size is unlikely to be carried out given the poor tolerance of diet.

The intolerance was investigated by Teahon $e t a l$ in a questionnaire survey of 89 patients receiving elemental diet. ${ }^{10}$ Nausea and postural hypotension were common in the first week, but after that only six patients found taste to be a problem. The main obstacle was usually the large volume of the diet (more than two litres a day), and only $65 \%$ of the patients said they would opt for the same treatment again. In our experience patients usually find the diet more tolerable if taken chilled. Alternatively, it can be taken by nasogastric tube. Manufacturers are trying to improve palatability, and the most commonly used elemental diet (E028, Scientific Hospital Supplies) is now available in prepared cartons with a taste similar to that of many soft drinks.

We think that, unless dietary treatment can be made more acceptable, a definitive trial comparing it with corticosteroids is not warranted. However, dietary treatment may still have a role as an adjunct to corticosteroid treatment, ${ }^{11}$ and confirmatory studies would be useful. Meanwhile, dietary treatment as a single agent should be available for those patients who do not want, or cannot tolerate, corticosteroids. Patients with Crohn's disease are often malnourished, and at the very least an elemental diet, which is absorbed high in the small bowel, is likely to be helpful at maintaining nutrition. If dietary treatment is used there are unproved but theoretical reasons to prefer elemental diet over polymeric diet.

Recently, oral budesonide has been shown to be better than placebo and similar to prednisolone in treating small bowel disease, ${ }^{12}$ and it seems to be largely free from many of the common short term side effects of corticosteroids. If it also proves to be freer of long term effects such as osteoporosis, it will have many of the hoped for advantages of an elemental diet and further reduce the need for dietary treatment.

Nick Wright Registrar

Brian B Scott

Consultant

Department of Gastroenterology,

County Hospital,

Lincoln LN2 5QY

1 Summers RW, Switz DM, Sessions JT, Becktel JM, Best WR, Kern F, et al. National cooperative Crohn's disease study: results of drug treatment Gastroenterology 1979;77:847-69.

2 Malchow H, Ewe K, Brandes JW, Goebell H, Ehms H, Sommer H, et al. European cooperative Crohn's disease study (ECCDS): results of drug treatment. Gastroenterology 1984;86:249-66.

3 American College of Rheumatology Task Force on Osteoporosis Guidelines. Recommendations for the prevention and treatment of glucocorticoid-induced osteoporosis. Arthritis and Rheumatism glucocorticoid-indu

4 O'Morain C, Segal C, Levi AJ. Elemental diet as primary treatment of acute Crohn's disease: a controlled trial. BMJ 1984;266:1859-62.

5 Gorard DA, Hunt JB, Payne-Jones JJ, Palmer KR, Rees RGP, Clark ML, et $a l$. Initial response and subsequent course of Crohn's disease treated with elemental diet or prednisolone. Gut 1993;34:1198-202.

6 Lochs H, Steinhardt HJ, Klaus-Wentz B, Zeitz M, Vogelsang H, Sommer $\mathrm{H}$, et al. Comparison of enteral nutrition and drug treatment in active Crohn's disease. Gastroenterology 1991;101:881-8.

7 Malchow H, Steinhardt HJ, Lorenz-Meyer H, Strohm WD, Rasmussen S, Sommer $\mathrm{H}$, et al. Feasibility and effectiveness of a defined-formula diet regimen in treating active Crohn's disease. Scand J Gastroenterol 1990;25:235-44.

8 Lindor KD, Fleming CR, Burnes JU, Nelson JK, Ilstrup DM. A randomized prospective trial comparing a defined formula diet, corticosteroids, and a defined formula diet plus corticosteroids in active Crohn's disease. Mayo Clin Proc 1992;67:328-33.

9 Gonzalex-Huix F, de Leon R, Fernandez-Banares F, Esteve M, Cabre E, Acero D, et al. Polymeric enteral diets as primary treatment of active Crohn's disease: a prospective steroid controlled trial. Gut 1993;34:778-82

10 Teahon K, Pearson M, Levi AJ, Bjarnason I. Practical aspects of enteral nutrition in the management of Crohn's disease. J Parenter Enteral Nutr 1995;19:365-8.

11 O'Brien CJ, Giaffer MH, Cann PA, Holdsworth CD. Elemental diet in steroid-dependent and steroid-refractory Crohn's disease. Am J Gastroenterol 1991;86:1614-8.

12 Sachar DB. Budesonide for inflammatory bowel disease. Is it a magic bullet? N Engl J Med 1995;331:873-4. 


\section{Detaining asylum seekers}

\section{Automatic independent judicial review would reduce unnecessary suffering}

$\mathrm{T}$ he recent hunger strike by asylum seekers detained at Rochester prison has brought to public attention the British government's practice of detaining some of those seeking political asylum. Between 750 and 800 such people are in British prisons or detention centres at any one time. Some remain detained for over a year. This practice is neither humane, nor, in most cases, necessary.

Britain has accepted international obligations to identify and protect refugees who have a genuine fear of persecution "for reasons of race, religion, nationality, membership of a particular social group, or political opinion." ${ }^{1}$ This necessitates procedures to decide which asylum seekers meet this criteria. Unfortunately, Britain's current procedures involve long delays before decisions are reached, and too often they fail to inspire confidence that the right decision has been made.

The most important consideration for asylum seekers when they arrive in Britain is to know that they have reached a place of safety. They are often exhausted and confused on arrival. Some may have only just left prison. Victims of torture may be near despair, clinging to the hope of safety and of a chance to live. Some of these asylum seekers, including victims of torture, will be detained in prisons or detention centres either on arrival or at some point during the government's decision making process. Lawyers and those who work with refugees are often at a loss to understand apparently arbitrary decisions to detain particular individuals, and the often equally unexplained decisions to release them.

Many medical studies report on the serious mental and emotional effects that detention has had on asylum seekers' health. ${ }^{2-4}$ In a recent study of detained asylum seekers, Dr Christina Pourgourides noted that "the responses to detention can manifest as symptoms which form constellations consistent with psychiatric diagnoses of depression, post traumatic stress disorder, anxiety and psychosis ... It should however be apparent that these symptoms can also be understood as universal manifestations of suffering and misery. This suffering and misery is generated by the practice of detention." $^{5}$

Non-medical reports on detention also refer to the suffering involved. In his report on a visit to Campsfield House Detention Centre in Oxfordshire, Judge Stephen Tumim, Britain's chief inspector of prisons, noted: "Detention without time limit, no matter how reasonable the conditions, is extremely stressful. When combined with ... the fact that some detainees appeared to be terrified at the prospect of being deported, the stress increases." ${ }^{6}$

The United Nations High Commissioner for Refugees takes the view that "in view of the hardship which it involves, detention should normally be avoided." 7 More recently the commissioner's guidance has been that "as a general rule, asylum seekers should not be detained," but if they are they should have "the right to challenge the lawfulness of the deprivation of liberty promptly before a competent, independent, and impartial authority." 8

The British government maintains that it uses detention very sparingly and only when it is essential to check identity, to prevent absconding, or to make it easier to remove people from Britain. But only a quarter of those detained are awaiting removal; the rest are still awaiting a decision. Of around 750 asylum seekers in detention in November 1996, 158 had already spent six months or more in detention. The Home Office adamantly refuses to have its decision to detain challenged automatically and independently in the courts. Thus the detention of asylum seekers amounts to detention for an indefinite period without charge or trial.

The main objection to the British system is the lack of any independent judicial control of the process. Internal reviews by the Home Office of the decision to detain are not sufficiently independent; bail hearings, habeas corpus, and judicial review applications are not automatic. Even individuals charged with terrorist offences have an automatic court hearing after seven days. It is essential that asylum seekers, who have not been charged with any offence, are guaranteed the opportunity to argue their case promptly before an independent and impartial judicial authority. If this were instituted, we believe that the number of those detained would be fewer and the length of detention shorter.

The government's detention policy should be seen in the context of increasingly restrictive asylum legislation. New legislation deprives many asylum seekers, some of whom are later recognised as genuine refugees, of the right to welfare benefits while they pursue their asylum claims.

Much of the pain of being a refugee cannot be prevented by the receiving country. The pain of exile and all that goes with it are well known. ${ }^{5}$ But the intense anxiety created by the present system in Britain makes meaningful rebuilding of lives much more difficult and leads to great and unneccesary human suffering.

Mary Salinsky Parliamentary liaison officer

Medical Foundation for the Care of Victims of Torture, London NW5 3EJ

1 United Nations. Convention relating to the status of the refugees. Article 1. Geneva: UN, 1951

2 Bracken P, Gorst-Unsworth C. The mental state of detained asylum seekers. Psychiatric Bull 1991;15:657-9.

3 Summerfield D, Gorst-Unsworth C, Bracken P, Tonge V, Forrest D, Hinshelwood G. Lancet 1991;338:58.

4 A betrayal of hope and trust. London: Medical Foundation for the Care of Victims of Torture, 1994.

5 Pourgourides CK, Sashidharan SP, Bracken PJ. A second exile: the mental health implications of detention of asylum seekers in the United Kingdom. Birmingham: North Birmingham Mental Health NHS Trust, 1995.

6 Home Office. Report of an unannounced short inspection by hm inspectorate of prisons, immigration detention centre, Campsfield House, London. London: Home Office, 1995.

7 United Nations High Commission for Refugees. Conclusions on the International Protection of Refugees adopted by the Executive Committee of the UNHCR Programme. Geneva:UNHCR,1991.

8 UNHCR Regional Bureau for Europe. Detention of asylum-seekers in Europe. European Series 1995;1(4):9-12. 


\title{
Primary managed care in Europe
}

\author{
Innovation by doctors is creating European health maintenance organisations
}

$\mathrm{P}$ rimary care is at the heart of the agenda for health policy in several countries. A recent management report from the Financial Times brings together information on the organisation and financing of primary care in five European countries and summarises government initiatives to strengthen primary care. ${ }^{1}$ As the report shows, primary care plays a bigger part in the health systems of Britain, Spain, and Italy than in France and Germany. Furthermore, there are many different approaches to organising primary care services and paying doctors. Government initiatives to move provision of health care to primary care include emphasising the gatekeeper role of general practitioners, developing the contribution of pharmacists as providers of primary health care, and using advances in healthcare technology to relocate services from hospitals to communities.

Reflecting its origins and the focus of the publishers, the report concentrates particularly on the implications of these developments for the drug industry. These include the switch of products from prescription only medicines to over the counter sales, the role of pharmacists as advisers on healthcare products, and the growing interest in disease management. Much less attention is given to developments in primary medical care and the role of nurses and other members of the primary care team.

A more general point follows, namely the challenge for researchers in keeping up with the rapid pace of change in primary care. Britain is a case in point. The establishment of fundholding, the policy of developing a primary care led NHS, and the publication of a consultation document and subsequently the white papers on primary care has resulted in a continually evolving agenda. Even more important, the innovations occurring within primary care itself have left policy makers struggling to keep up with developments on the ground. Given that these changes are as much the result of bottom up innovation as top down policy initiatives, analysts seeking to identify trends in primary care need to look beyond government statements of intent to examine much more closely what is happening in practice.

Reading the tea leaves, I suggest that, in an era in which European governments are striving to control public spending in order to meet the convergence criteria agreed at Maastricht for progress towards monetary union, politicians will place even greater emphasis in future on primary care. This will be stimulated in part by a concern to control costs by limiting the use of expensive secondary and tertiary care services, and in part by a wish to take advantage of advances in technology to deliver a higher proportion of care in the community. As this happens, primary managed care ${ }^{2}$ looks set to replace managed competition as the next fashion in healthcare reform.

But what exactly is managed care? This term is usually invoked in the United States to describe the emergence of health maintenance organisations (HMOs) and similar initiatives. As recent developments indicate, there are moves afoot to export managed care to other countries. ${ }^{3}$ In Europe, the scope for importing American ideas is limited, if only because health systems in Europe have long recognised the need to manage health care with the aim of containing costs and raising quality. In Europe this includes using primary care doctors as gatekeepers (in some countries); standardising clinical practices through the application of guidelines, protocols, and care pathways; using financial incentives to influence clinical practice patterns; developing information systems to monitor the use and cost of services; and informing and educating patients to take greater responsibility for their own health.

In the context of the Financial Times report a particularly important recent development is the introduction in Britain of PRODIGY, a computerised information system offering advice to general practitioners on prescribing and non-drug treatments for common conditions. Also important is the extension of general practice fundholding into total purchasing. Doctors in the total purchasing projects are already using an array of managed care techniques, even though they may not use this language. This includes general practitioners paying greater attention than in the past to managing individual cases and changing the use of hospital services by questioning specialists' decisions. The introduction of total purchasing, together with the establishment of multifunds and commissioning groups of general practitioners, has changed the landscape of British primary care and heralds the emergence of European style health maintenance organisations. ${ }^{4}$

The danger here, as America's experience of managed care shows, is that doctors' decisions will be so tightly controlled that they will become mere technicians. If the momentum behind managed care does gather pace, the challenge will be to avoid this danger while creating stronger incentives for efficiency and responsiveness on the part of service providers. And, as American experience also demonstrates, primary and secondary care must be closely integrated to avoid fragmentation and duplication. In the vocabulary of managed care analysts, virtual integration rather than vertical integration ${ }^{5}$ looks likely to prevail as networks rather than hierarchies are used to achieve seamless service delivery.

Chris Ham Director

Health Services Management Centre,

University of Birmingham,

Birmingham B15 2RT

1 Zayed H, Manning S. Primary care. A profile of the major European markets. London: Financial Times Pharmaceutical and Healthcare Publishing, 1995.

2 Robinson B. Primary managed care: the Lyme alternative. In: Meads G, ed. Future options for general practice. Oxford: Radcliffe Medical Press, 1996. 3 Smith R. Global competition in health care. BMJ 1996;313:764-5.

4 Smith J, Bamford M, Ham C, Scrivens E, Shapiro J. Beyond fundholding: a mosaic of primary care led commissioning and provision in the West Midlands. Birmingham: University of Birmingham,1997.

5 Robinson JC, Casalino LP. Vertical integration and organisational networks in health care. Health Affairs 1996;15:7-22. 


\title{
The community's response to mentally ill people
}

\author{
Can be improved
}

$\mathrm{A}$

ll societies have struggled with the impact of mental illness, and rejection and avoidance of mentally disabled people are common. Even when the mad have been accorded a place of honour, as in cultures that believe mentally ill people have been touched by the Great Spirit, they have remained outside the group and have been feared. Today this fear continues to obstruct moves towards caring more humanely for mentally ill people in the community. Many of those fears are unfounded and others may be allayed by sensible policy making.

Modern day psychiatry is empirically driven and biochemically oriented. After 400 years of development and reform many would say that, with all their flaws, psychiatric institutions provide relief and treatment to their patients. This judgment contrasts sharply with the anachronistic brouhaha of civil libertarians and the "consumer-survivor movement." Community care and the corresponding deinstitutionalisation would not have occurred or succeeded without concomitant advances in the neurosciences and psychopharmacology. Deinstitutionalisation has been achieved despite government parsimony in funding professional community services and misguided statutes restricting the treatment of florid psychosis, which have had disastrous consequences for many patients.

Studies in the United Kingdom, the United States, and Australia reveal that good community care is preferred by patients and relatives. ${ }^{2}$ Common sense dictates that where the response of the community is negative the likelihood of relapse and exacerbation of symptoms increases and survival in the community decreases. From Hong Kong to London to New York the initial community responses to community care have not been positive. The "not in my backyard" (NIMBY) response is universal.

These responses operate on numerous planes. Fears for the safety of the individual and his or her family appear to be paramount. ${ }^{3}$ They are followed by perceptions of a decline in property values, physical deterioration in neighbourhoods, exposure to bizarre behaviour, and increased noise and traffic congestion. In many cases local authorities have heeded such complaints and enacted restrictive zoning bylaws which preclude the opening of group homes.

The public's perceptions and responses have recently been skilfully, exhaustively, and rigorously presented in a series of articles in the British Journal of Psychiatry. These articles were precipitated by the closure of Tooting Bec Hospital, an asylum in south London, and the opening of additional group homes. ${ }^{4-6}$ The attitudes and beliefs of people living in the areas where the group homes were planned were examined along three dimensions which had predictive validity in relation to community responses towards the mentally ill. The cardinal factors extrapolated were labelled fear and exclusion, social control, and goodwill. Expressions of fear of the mentally ill were correlated with negative responses towards them. Feelings that the mentally ill required social control and the absence of goodwill were less powerful indicators of rejection.

Interestingly, negative attitudes based on fear are not restricted to placement in the community. In Japan the public's fear of assault and antipathy towards the mentally ill were expressed in community opposition to the opening of institutions. ${ }^{8}$ Fortunately strategies exist to neutralise this almost visceral response. Destigmatisation, social interaction, and friendships occur when the media and public education campaigns attend to the issues and fears noted above. A solid body of empirical research has shown that property values do not decrease and neighbourhoods do not deteriorate. ${ }^{9}$ Violence is not a major problem among treated patients. ${ }^{10}$ This information can be used to allay discomfiture and neutralise discriminatory practices.

Community care should not be just about the closure of mental hospitals but about providing adequate treatment. Community care and institutional treatment should not be at war. Treatment of a biopsychosocial nature is what matters not whether it is intramural or extramural. Nevertheless, the careful selection of patients to be placed in community living and round the clock availability of professional help are indispensable ingredients for successful programmes. ${ }^{11}$

Bureaucratic indifference to inadequate funding, legislative indifference to untreated psychotic behaviour, and the lack of compliance with treatment plans where violence is an issue do much to reinforce public hostility to community care. Health planners cannot and must not be oblivious of society's responsibility for the treatment of the vulnerable mentally ill.

Sam Sussman

Director of social services

London and St Thomas Psychiatric Hospital,

St Thomas,

Ontario N5P 3VP,

Canada

1 Wing J. Vision and reality. In: Hall P, Brockington I, eds. The closure of mental hospitals. London: Gaskell, 1991

2 Marks I. Innovations in mental health care delivery. Br J Psychiatry 1992;160:589-97.

3 Cheung F. People against the mentally ill: community opposition to residential treatment facilities. Comm Ment Health J 1990;26:205-12.

4 Wolff G, Pathare S, Craig T, Leff J. Community attitudes to mental illness. BrJ Psychiatry 1996;168:183-90.

5 Wolff G, Pathare S, Craig T, Leff J. Community knowledge of mental illness and reaction to mentally ill people. BrJ Psychiatry 1996;168:191-8.

6 Wolff G, Pathare S, Craig T, Leff J. Public education for community care, a new approach. Br J Psychiatry 1996;168:441-7.

7 Wolff G, Pathare S, Craig T, Leff J. Community attitudes to mental illness. Br J Psychiatry 1996;168:183-90.

8 Oshima I, Ueda H. Social conflict between institutions for the disabled and the general inhabitants: A nationwide distribution of the conflict and its factors. J Ment Health 1990;36:101-12.(In Japanese with English abstract.)

9 Arens D. What do the neighbours think now? Community residences on Long Island, New York. Comm Ment Health J 1993;29:235-45.

10 Torrey F. Violent behaviour by individuals with serious mental illness. Hospital and Community Psychiatry 1994;45:653-62.

11 Stein L. Creating change: a case study. In: Dean C, Freeman H, eds. Community mental health care: international perspectives on making it happen. London:Gaskell,1993. 


\title{
Food for independence
}

\author{
To distance the sponsors of commercial interests from the defenders of consumer health
}

$\mathrm{T}$ he British government's announcement that it will establish a new Food Safety Council and appoint a Food Safety Adviser ${ }^{1}$ has received a cautious welcome. However, the decision that both offices will be accountable to ministers while, at the same time, being independent, has rekindled the argument about how independent such bodies can be. ${ }^{2}$

Complete independence from government is almost impossible. Bodies must be appointed and funded by someone with authority to spend public money. Most democracies balance accountability and independence by taking advantage of the separation of the powers of the executive (ministers), the legislature (parliament), and the judiciary. Bodies tackling potentially controversial issues, which must provide authoritative advice and retain public confidence, can be accountable to the legislature, giving them freedom to challenge, where necessary, the executive. A second model is based on decentralisation, with local and national government as more equal partners.

The United States Food and Drug Administration, accountable to Congress, is often considered a model for a reformed British food safety organisation. But realisation of the administration's costs might make its attractions wane. Both the Conservative and Labour parties in Britain promise fiscal rectitude after the election. No politician wants to increase the food and agriculture budget, given the extra $£ 3.3$ billion needed since the bovine spongiform encephalopathy crisis blew up in March last year.

Other models others deserve consideration. In the early 1990s, Australia established a National Food Authority to give central guidance from the federal government. ${ }^{3}$ Norway's national food policy, established in the mid-1970s, integrates relevant sectors to produce a programme combining public health, the environment, employment, and rural policies. ${ }^{4}$ Denmark also established a national food administration; but, at least one of its former heads has now publicly called for it to be returned to a reformed Ministry of Food, arguing that the food system is too important to be left to "arm's length" decisions. ${ }^{5}$

However, none of these countries has Britain's centralised system, with its very strong executive. Perhaps a more appropriate model is that of Ireland, where a Food Safety Board was established in response to loss of consumer confidence over bovine spongiform encephalopathy. ${ }^{6}$ Unlike the British proposals, which were greeted with considerable scepticism, ${ }^{7}$ this received general approval, apart from opposition politicians, because the board excludes industry representatives.

Whatever model is adopted, to be credible in the eyes of the public but also effective at influencing policy it must take account of the reality of British political structures. The blurred borders between the executive and the legislature in Britain, and the absence of decentralisation, make this especially difficult. To some extent these problems can be overcome, as shown by the National Audit Office's accountability to parliament, which has enabled it to issue reports that have been highly critical of certain government actions.

This is a rare exception, however, and ministers have been loath to encourage the principle. Furthermore, although many parliamentary committees have worked hard to safeguard their independence, their inbuilt government majority is a fundamental weakness; and the example of the appointment of a government whip to the committee investigating the "cash for questions" affair-where payments were made to members of parliament in return for favours-shows what can happen when the political stakes are high. And any separation of powers that did exist has been steadily eroded in recent years, with the increasing control exerted by the political parties over backbench members of parliament. ${ }^{8}$

The challenge of being, and being seen to be, independent is one faced by many governmental organisations in Britain. In the same week as the new Food Safety Council was announced, the Office for National Statistics withdrew the new edition of Social Trends when it was realised that this showed government spending on the NHS falling in recent years after adjustment for national economic growth. A revised version contained a set of figures, adjusted only for inflation, that showed continuing growth. Whatever the technical arguments, this has caused some to voice concern about the difficulty the office faces in retaining independence. ${ }^{9}$ There is considerable irony, as it was the separation of crown and parliament in England, and the contrast with France, that inspired Montesquieu, who went on to influence the formal separation enshrined in the American constitution. ${ }^{10}$

Clearly, Britain needs a change in the way ministers are advised on food policy. The new structures are a first step, but we must learn from the lessons of others. The key to success is trust, but existing British political structures place obstacles in the way of restoring trust. In these circumstances, the very least that should happen is that there should be more distance between the sponsors of commercial interests within a government ministry and those whose task is to defend the consumer's health. ${ }^{11}$

\section{Martin McKee Professor of European public health}

London School of Hygiene and Tropical Medicine,

London WC1E 7HT

Tim Lang

Professor of food policy

Wolfson School of Health Sciences,

Thames Valley University,

London W5 5RF

1 Ministry of Agriculture, Fisheries and Food. Government to appoin independent adviser on food safety. London: MAFF, 1997. (News release, 30 January.)

2 Brown P. Hogg's food safety watchdog "will have limited powers." Guardian 1997 January 31:10. 
3 National Food Authority. Annual report 1991-92. Canberra: Australian Government Publishing Service, 1992:5-12.

4 Royal Norwegian Ministry of Agriculture. On Norwegian nutrition and food policy. Oslo: Norwegian Government: 1976. (Report no 32 to the Storting (1975-76).)

5 Jensen, JH, chair. Mal og midler i femtidens konlrol med levnedsmidler. Lyagby: Akademiet for de tekniske Videnskaber, 1995

6 Tynan MM. New Food Safety Board given mixed reception. Irish Times 1996 October 31.
7 Urry M, Parker G. Food safety overhaul met with caution. Financial Times 1997 January 31.

8 Jenkins S. Accountable to none. Hamish Hamilton: London, 1995

9 Health spending is up: or down. Guardian 1997 January 31:18.

10 Ouinton A. Political philosophy. In: Kenny A, ed. Oxford illustrated history of western philosophy. Oxford: Oxford University Press, 1994.

11 Lang T, Millstone E, Raven H, Rayner M. Modernising UK food policy: the case for reform of the Ministry of Agriculture, Fisheries and Food. London: Centre for Food Policy, Thames Valley University, 1996.

\section{Europe matters}

\section{And doctors should get involved}

$\mathrm{W}$ hen "Europe" comes up on the agendas of medical organisations in Britain, many in the audience switch off. They have little interest in Europe. They don't think it matters to them. But this insular view is wrong. European legislation has had a major impact on medicine in Britain, and the week before the European parliament responds to a new proposal from the European Commission to reorganise the way it deals with health seems a good time to draw attention to this.

The current upheaval in postgraduate specialist training, caused by the reorganisation in the wake of the Calman report, ${ }^{1}$ has its origins in the European Union. It was prompted by the commission's threat to take the British government to the European Court of Justice for not observing union law on mutual recognition of qualifications. This law has also enabled Britain to employ graduates trained elsewhere in the union to plug the growing gap at senior house officer level and, increasingly, in general practitioner vocational training schemes. The number of such graduates registered in Britain has risen from 1020 in 1990 to 2067 in 1996. And while the new deal on junior doctors' hours was not drawn up to appease Brussels, it has undoubtably been fuelled by the union's 48 hour working time directive.

It is a paradox that British medicine, as these examples show, has been so affected by membership of an entity that many people know little about. Despite the Channel tunnel, we still find it difficult to relate to Europe in a way that most other Europeans take for granted. It is easy to be alienated by the idiosyncratic workings of the union's institutions, the complex way they interact, and the reams of inaccessible documents they produce.

But it is important to engage with Europe, especially as 1997 is a crucial year for the European Union. The European institutions face huge challenges as they prepare for economic and monetary union and the enlargement of the union to incorporate up to 13 additional countries. And later this year, the intergovernmental conference is due to culminate with the signing of a new, post-Maastricht, European treaty.

Health will not feature strongly in the new treaty, for it is not and never has been one of the union's priorities. Nevertheless, health issues have been moving up the European agenda, and the recent crisis over bovine spongiform encephalopathy has escalated concern about consumer protection and public health. In response the union's president, Jacques Santer, has proposed that the sectors responsible for food safety and veterinary inspection should be moved out of the large industry and agriculture directorate generals (departments) to a small and relatively new directorate general. Currently responsible for consumer affairs and headed by Commissioner Emma Bonino, this department looks set to be upgraded to cover "consumer policy and health."

Although there has been considerable pressure from both the European parliament and various European lobby groups to establish a designated directorate general for health, it is doubtful if this hasty piece of portfolio shuffling will achieve much. Tacking "consumer health" onto a new directorate general and leaving "public health" in its current position in the directorate general for social affairs and employment, where it tends to play third fiddle, will not provide the broad, well supported base that has been called for. The health interests in the commission remain fragmented in several different departments. Unless they are drawn together, it is hard to see how the union can develop a comprehensive, forward looking public health policy or how the community's mandate to take the health effects of other union policies into consideration can become more than a paper exercise.

Although next week's decision is not set to trigger a sea change in how the union deals with health, it should raise its profile. This should put the discussions on health policy into sharper focus. Members of the European parliament, health ministers, commision officials, health policy experts, and European lobby groups are actively engaged in these debates. Doctors, by comparison, are not. The European doctors associations, in particular, seem more interested in professional issues than public health. Arguably the profession should muster more enthusiasm and concern about the European Union's health initiatives and contribute more fully to shaping their future development.

Tessa Richards Associate editor

$B M J$,

London WC1H 9JR

1 Beecham L. Trying to satisfy EC directives on specialism. BMJ 1992;305:332.

\section{Correction}

\section{Hangovers}

An author error occurred in this editorial by Ian Calder (4 January, pp 2-3). The concentration of methanol in bourbon whiskey is $26 \mathrm{mg} / \mathrm{l}$ (rather than $260 \mathrm{mg} / \mathrm{l}$ as stated) and in vodka is $3.9 \mathrm{mg} / \mathrm{l}$ (rather than $0.039 \mathrm{mg} / \mathrm{l})$. 